Mospan Natalia ORCID iD 0000-0001-8610-7965

$\mathrm{PhD}$, Associate Professor of English Philology and Translation Department, Borys Grinchenko Kyiv University, 13-b Tymoshenko Str., 04212 Kyiv, Ukraine n.mospan@kubg.edu.ua

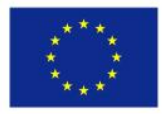

Co-funded by the Erasmus+ Programme of the European Union

\title{
QUALITY ASSURANCE ORGANISATIONAL AND MANAGEMENT STRUCTURE IN THE EUROPEAN UNION
}

The article presents the features of the quality assurance management system of higher education in the EU. Besides, the analysis of the quality assurance system in Europe, namely its external and internal organs is in th the center of attention. External mechanisms include education quality assurance regulators at the EU and the EHEA level and national regulators of education quality assurance at the level of Member States. Internal mechanisms are made up of quality control departments within HEIs. It was concluded that the organizational and administrative structure adjustment of standards and quality assurance of education in the EU subject to their own hierarchy, where each mechanisms interact to ensure the quality of the various higher education systems. This system of organizational and management structures regulation of standards and quality assurance of education in the EU allows to implement universe standards of quality assurance in higher education in all EU Member States and countries in the EHEA. However, despite the establishment of relatively universe shape of quality assurance system, there are significant differences in approaches to the system at the national level.

Key words: external quality assurance; higher education; internal quality assurance; quality assurance system; the EU.

Introduction. Creating and expanding the EU with its high degree of integration of the economy and labour markets is one of the strongest impacts for developing common standards and quality assurance in higher education. Quality standards are widely used to determine the quality of services to meet the clients and employers' needs who are the main customers of the "product" of higher education. In turn, the student population, as a customer of an educational service, also feels the need for higher standards of higher 
education quality, realizing under this their "suitability for practical use" (Internal Quality Assurance Systems, 2011, p. 2).

Quality assurance systems in Europe appeared under pressure from the needs of society in greater accountability of universities and they were first launched in the UK, the Netherlands and Denmark. A strong impetus for the establishment of national quality assurance systems was the adoption of the Lisbon Convention on Recognition in 1997, based on the mutual recognition of qualifications and mutual trust between higher education systems. Since then, quality improvement, the demand for higher education, and the establishment of a reliable quality assurance system have had a high priority for all EHEA countries. The Bologna Declaration has become even more powerful quality assurance tool, where HEIs have been given a decisive role in developing reliable internal systems for quality assurance.

In scientific literature, the issue of quality assurance in higher education attracts considerable attention of researchers, but the issue of the organizational and management structure of regulation of quality assurance in education is not sufficiently highlighted. Accordingly, the purpose of the article is to define the quality assuranse management system in higher education in the EU, based on the study of authentic documents and reports.

The study of scientific literature on the management structure of the quality assuarance in higher education in the EU has shown that this system consists of external and internal mechanisms for quality assurance in higher education (Focus on the Structure of Higher Education, 2007; Internal Quality Assurance Systems, 2011; European Commission / EACEA / Eurydice, 2015). However, the views of scholars are scattered over the question of exactly which structures relate to external or internal mechanisms of quality assurance in higher education.

In his report, Tück C. (2008) identifies three types of higher education quality assurance structures: 1) external QA agencies; 2) external QA of HEIs; 2) internal QA by HEIs. Loukkola T. (2015) identifies three other types of higher education quality assurance structures: 1) internal QA at HEIs; 2) external QA carried by QAAs; 3) internal QA within QAAs. Studing the structure of higher education in the EU, researchers 
highlight national bodies for quality assurance (Focus on the Structure of Higher Education, 2007, 37-39), as well as internal Quality Assurance or Quality Management systems (Internal Quality Assurance Systems, 2011). Based on these studies, we determine that external mechanisms include quality assurance management bodies at the EU level, at the level of EU Member States and EHEA. Internal mechanisms of quality assurance management bodies within the university (see Fig.1.). Internal and external quality assurance is mandatory in the most countries, with the exception of Andorra, Armenia, Austria, Bosnia and Herzegovina, Luxembourg and Malta. In Cyprus, this is a demand for private universities (Focus on the Structure of Higher, 2007, p. 48-49).

Fig.1 Quality Assurance System in the EU

\begin{tabular}{|c|c|}
\hline Internal quality assurance & External quality assurance \\
\hline \multirow{2}{*}{ at HEIs level } & at the international level / EHEA \\
\cline { 2 - 2 } & at the EU level \\
\cline { 2 - 2 } & at the EU Member States level \\
\hline
\end{tabular}

External quality assurance bodies at the EU level. Adoption of the Standards and Recommendations of Quality Assurance in the European Higher Education Area (ESG) in 2005 has given impetus to European cooperation, where two organizations, in particular, play a significant role in the creation of external quality assurance agencies for higher education.

The European Association for Quality Assurance in Higher Education (ENQA) was established in 2000 to promote cooperation between agencies of the quality assurance in higher education and requires its members to adhere to standards and promote the exchange of the best practice between universities (ENQA). The Association conducts an external review of HEIs by independent experts in the field of quality assurance, and also takes all decisions related to the registration of national quality assurance systems in the EU member states. Its mission is to ensure transparency and information about the results of the quality assuarance of the activities of the universities and educational programmes. Among the tasks are increased confidence and recognition of evaluation results, 
recognition of qualifications and periods of learning, as well as granting permission for registered quality assurance agencies to work throughout the EHEA, and their HEIs - to select an agency for conducting an assessment (An Overview of External Quality 2014).

The European Quality Assurance Register in Higher Education (EQAR) was established in 2008 to enhance the transparency of quality assurance in higher education throughout Europe. The register provides reliable information on quality assurance agencies operating in Europe, thereby maintaining the trust of those quality assurance agencies that wish to work across national borders within the EHEA. The EQAR publishes and manages a register of quality assurance agencies that meet Standards and Guidelines for Quality Assurance in the European Higher Education Area to provide the public with clear and reliable information about EQAR of quality assurance agencies in Europe. "The purpose of the register is to provide all stakeholders and the general public with open access to objective information about reliable quality assurance agencies operating in accordance with ESG" (London Communique, 2007). The register promotes cross-border recognition of quality assurance agencies, according to the Bucharest Communiqué, which "allows registered agencies in the EQAR to carry out their activities throughout the EHEA, while respecting national requirements" (Bucharest Communique, 2012).

An important role in providing quality assurance in higher education in the EU plays the networks of information centers that cover all countries of Europe, Canada, Israel, the United States and New Zealand. They provide information on the higher education systems of the EU Member States and the EHEA accreditation agencies.

The European Network of Information Centres in the European Region (ENIC) implements the Lisbon Convention on Recognition and, in general, develops policies and practices for the recognition of qualifications. The European network consists of national information centers of the member-states and is a part of the European Cultural Convention or UNESCO. It is a body created by the national authorities to provide information on the following issues:

- recognition of foreign diplomas, degrees and qualifications; 
- education systems in both foreign countries and countries from the European network;

- opportunities for studying abroad, including information on loans and scholarships, as well as recommendations on practical issues related to student mobility (List of recognized organizations).

The European Network works closely with the Network of National Academic Recognition Information Centers (NARIC). This network aims to improve the academic recognition of diplomas and periods of study in the Member States, the European Economic Area and Turkey. It is a part of the EU lifelong learning program, which stimulates the mobility of students and staff between universities. All the EU member states have identified national centers whose purpose is to help promote the mobility of students, teachers and researchers by providing authoritative advice and information on academic recognition of diplomas and periods of study received in other countries. The main consumers of this service are universities, students, teachers and potential employers.

It is worth noting that in most countries the universities are autonomous, so they make their own decisions on admitting foreign students and canceling the curricula that may be accepted by students for studying abroad. As a result, the most Network Information Centers do not make decisions, but offer information and advice on foreign education and training systems (List of recognized organizations).

Direction of external quality assurance in higher education. Although the most of all the EHEA countries establish a certain form of external quality assurance system, researchers highlight significant differences in approaches to the system. The main difference is the purpose and direction of external quality assurance:

- in regulating the effectiveness of universities and programmes;

- in funding universities or programmes;

- in determining the quality of programmes or activities of the HEIs.

In higher education systems, where agencies have the right to allow or refuse programmes or universities to work, they play a role of external quality assurance bodies. Higher education systems that have created agencies with decision-making powers are 
dominated by two to one over those where the bodies are oriented on giving information or improvement of higher education quality (European Commission/EACEA/Eurydice 2015, p. 90).

The impact of external quality assurance on financing varies considerably depending on the characteristics of the system. Thus, the funding of universities and curricula depends on the decision of quality assurance systems that are of supervisory charachter. However, systems in which quality control is aimed at improving the performance of higher education institutions does not affect financing more often. Latvia and Malta are in the process of improving the quality assurance system. Russia, the largest system in the EHEA, is also highlighted as a country with variable quality systems. In particular, the system of state accreditation operates in parallel with quality assurance agencies that are full members of the European Quality Assurance Association in Higher Education (European Commission/EACEA/Eurydice 2015, p. 91).

External quality assurance at the national level. The EHEA has started the development of national quality assurance systems that differ in terms of responsibilities, depending on the national specificities of the higher education system. Thus, Austria, the Flemish Community of Belgium, Croatia, France, Germany, Ireland, Macedonia, the Netherlands and Spain have more than one independent quality assurance authority. These bodies are responsible for only one region in one country or another, or there are separate bodies for different types of universities or curricula. In France, the National Evaluation Committee is responsible only for the external evaluation of the university. In six countries (Bosnia and Herzegovina, German-speaking Community of Belgium, Cyprus, Liechtenstein, Luxembourg and Malta), there is no national body for the quality assurance in higher education. The independence of the national quality assurance agency is one of the criteria for accepting it as a full member of the European Association for Quality Assurance in Higher Education (Focus on the Structure of Higher, 2007, p. 37-38).

The European quality assurance process emphasizes the importance of trust between education systems. One important measure of confidence is the permission of the HEI government to be evaluated by quality assurance agencies in another country where the agency works in full compliance with ESG. National responsibility for quality assurance 
can be perceived and challenged, therefore, some countries do not dare to accept responses by non-national agencies, especially in those systems where the main result of the quality assuarance is the decision to grant permission for the functioning of universities or programs (European Commission/EACEA/Eurydice, 2015, p. 94).

Internal quality assurance at the HEIs level. Almost all countries require from universities to create internal quality assurance systems based on national legislation. According to the European Commission's report on fulfilling these requirements for 2015, in the vast majority of higher education systems (37) universities are responsible for the internal quality assurance of education. However, Estonia and Switzerland are the only countries of the EHEA where this is not a formal requirement.

Establishment of internal quality assurance bodies in HEIs is complicated by the autonomy of universities, which in most countries can establish internal quality assurance systems at their discretion (Internal Quality Assurance Systems, 2011, p.3). Investigation of this issue by a group of scientists showes that in some countries (Latvia, Poland) the creation of a system of internal quality assurance was not directly provided for by national legislation. Nevertheless, some universities in these countries have set up their own Quality Assurance or Quality Management Systems that have been certified by external quality assurance agencies, some of which have been recognized at the national level, and some have been adopted by management authorities of institutions. Quality management structures have been established either according to international standards (ISO 9001: 2008), or on the basis of standards existing in certain branches of the economy, or according to templates developed by national quality assurance agencies.

The structure of internal quality assurance management is coordinated at the central level, but has options with the responsible person, depending on the size of the university and national traditions. The responsible person is the Vice-Rector for Academic Affairs (Latvia, Czech Republic and Poland), Quality Management Division (Latvia, Czech and Polish Republic, United Kingdom), Academic Department (Latvia), Educational Center (Netherlands), Office for the Evaluation and Institutional Quality Promotion (Portugal) (Internal Quality Assurance Systems, 2011, p. 8). 
Among the factors that influence the process of quality assurance, researchers highlight external quality assurance. In particular, a number of countries show that external quality assurance has a strictly defined framework. Therefore, even if universities are formally responsible for making decisions on the priorities of their internal quality assurance management, in reality the external framework of quality assurance significantly limits the actions of HEIs in making decisions (European Commission/EACEA/Eurydice, 2015, p. 88).

Nevertheless, many countries report a positive trend towards creating internal quality assurance systems in the EU. The authors of the 2015 report assert that in 33 national higher education systems, $75 \%$ of universities have adopted their institutional strategies for continuous improvement of quality (European Commission/EACEA/Eurydice, 2015, p. 89).

Fig. 2. Quality Assurance Regulation in the EU

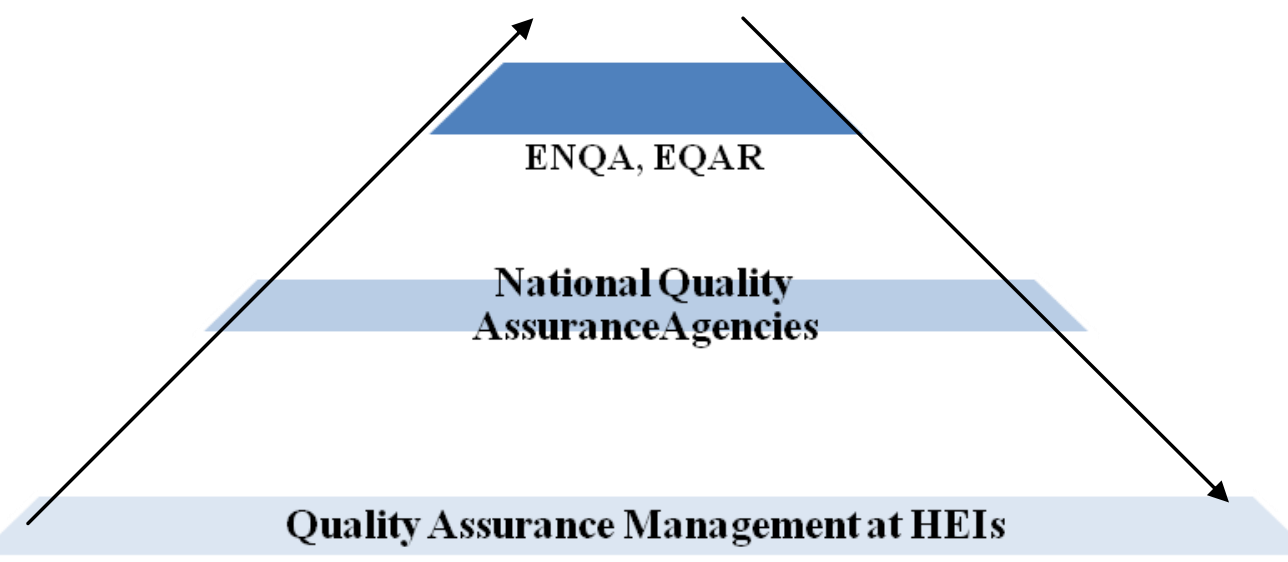

Crosier D. and Parveva T. point out that there are significant differences in the goals and approaches of existing quality assurance systems. One important difference lies in the facility focusing on agencies - at universities, programmes, or both (Crosier D., Parveva T. The Bologna Process, 44). They also note that most of the quality assurance systems in higher education in the EHEA are primarily controlling in nature. Such organizations have the power to allow or prohibit the functioning of programmes or HEIs. They can also perform other functions: to provide advice on improving quality (Crosier D., Parveva T. The Bologna Process, 47). 
From the said abouve it is possible to assert that the quality assurance system includes external and internal quality assurance mechanisms based on ESG, where the EQAR is a source of information about the system as a whole (see Fig.3).

\section{Fig. 3. Quality Assurance Mechanisms in Higher Education in the EU}

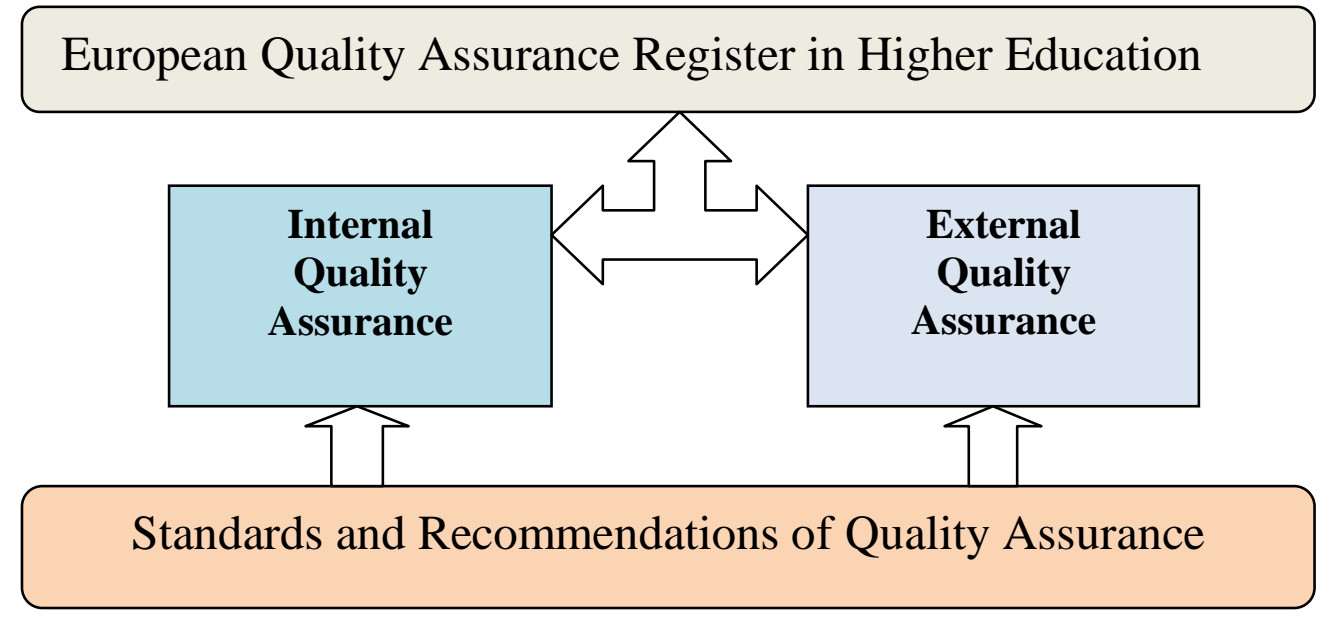

Conclusions. Thus, the study leads to concludind that quality assurance manegement system in higher education in the EU are subject to its own hierarchy (see Figure 2), where each mechanism interacts with each other to ensure the quality to different higher education systems. The main role in this hierarchy belongs to external quality assurance bodies (ENQA, EQAR and networks) whose function is to regulate the effectiveness of HEIs and educational programs, as well as to monitor national agencies for compliance with the ESG in itheir activities. The role of 'executive body' in the regulation of the quality assurance management system in higher education is carried out by national quality assurance agencies that must be a full member of the European Association for Quality Assurance in Higher Education or registered in the European Register to obtain the right to accredit as their higher education systems so and overseas. The last link is the internal quality assurance bodies at universities that carry out 'selfmonitoring' on the ground. Such a system of quality assurance management in higher education in the EU allows the implementation of common standards for the quality of higher education in all the EU Member States and in the EHEA. 
This study is fuifilled under the Jean Monnet Activities within the ERASMUS+Programme Project "Higher Education Quality and Its Expert Support: Ukraine's movement towards the European Union“. Contents of the article reflects only the author's view, the Education, Audiovisual and Culture Executive Agency and the European Commission are not responsible for any use that may be made of the information it contains.

\section{References}

An Overview of External Quality Assurance Developments within EHEA. Retrieved from http://adm.archimedes.ee/inqaahe/files/2014/05/Melinda-Szabo.pdf (eng).

Bucharest Communiqué. Making the Most of Our Potential: Consolidating the European Higher Education Area (2012). Retrieved from https://media.ehea.info/file/2012_Bucharest/67/3/Bucharest_Communique_2012_61 0673.pdf (eng).

ENQA. European Association for Quality Assurance in Higher Education. Retrieved from http://www.enqa.eu/ (eng).

European Commission/EACEA/Eurydice. The European Higher Education Area in 2015: Bologna Process Implementation Report (2015). Luxembourg: Publications Office of the European Union. Retrieved from http://www.ehea.info/Uploads/SubmitedFiles/5_2015/132824.pdf (eng).

Focus on the Structure of Higher Education in Europe 2006/07 National Trends in the Bologna Process (2007). Brussels: Eurydice, 350. Retrieved from http://eacea.ec.europa.eu/education/eurydice/documents/thematic_reports/086en.pdf (eng).

Internal Quality Assurance Systems. Cross-country comparative study (2011). Retrieved from http://www.ibar-llp.eu/assets/files/wp5/WP5\%20Crosscountry\%20comparative\%20study.pdf (eng).

List of recognized higher education accreditation organizations. Retrieved from https://en.wikipedia.org/wiki/List_of_recognized_higher_education_accreditation_o rganizations (eng).

London Communiqué. Towards to the European Higher Education Area: responding to challenges of the globalised world (May 18, 2007). Retrieved from https://www.coe.int/t/dg4/highereducation/EHEA2010/London\%20Communique\%2 0-\%2018-05-2007.pdf (eng).

Loukkola, Tia (2015). ESG 2015 - What has changed and what does it mean for QA practitioners? Retrieved from http://www.equip-project.eu/wpcontent/uploads/EQUIP_160509-10_Vienna_pres_LOUKKOLA.pdf (eng).

Tück, C. (May 26/27, 2008). Quality Assurance in the European Higher Education Area. Baku. Council of Europe seminar. (eng). 


\section{ОРГАНІЗАЦІЙНО-УПРАВЛІНСЬКА СТРУКТУРА ЗАБЕЗПЕЧЕННЯ ЯКОСТІ В ЄВРОПЕЙСЬКОМУ СОЮЗІ}

Мосьпан Наталія, кандидат педагогічних наук, доцент кафедри англійської філології та перекладу, Київський університет імені Бориса Грінченка, вул.

Тимошенка, 13-б, 04212 Київ, Україна, n.mospan@kubg.edu.ua

У статті обгрунтовано особливості організаційно-управлінської структури забезпечення якості вищзої освіти в ЄС. Проаналізовано системи забезпечення якості в Свропі, а саме ї̈ зовнішні та внутрішні органи. Зроблено висновок, шзо структури регулювання системи якості освіти в СС підпорядковуються власній ієрархї, де кожні механізми взаємодіють між собою для забезпечення якістю різних систем вищуої освіти. Проте, незважаючи на встановлення відносно однакової форми зовнішньої системи забезпечення якості, існують значні відмінності в підходах до системи на національному рівні.

Ключові слова: вищза освіта; внутрішні органи забезпечення якості; $Є C$; зовнішні органи забезпечення якості; система забезпечення якості освіти.

\section{ОРГАНИЗАЦИОННО-УПРАВЛЕНЧЕСКАЯ СТРУКТУРА ОБЕСПЕЧЕНИЯ КАЧЕСТВА В ЕВРОПЕЙСКОМ СОЮЗЕ}

Мосьпан Наталия, кандидат педагогических наук, доцент, доцент кафедры английской филологии и перевода, Киевский университет имени Бориса Гринченка, ул. Тимошенко, 13-б, 04212 г. Киев, Украина, n.mospan@kubg.edu.ua

В статье обоснованы особенности организационно-управленческой структуры обеспечения качества высшего образования в ЕС. Проанализированы системь обеспечения качества в Европе, а именно ее внешние и внутренние органы. Сделан взвод о том, что структуры регулирования системы качества образования в ЕС подчиняются собственной иерархии, где каждые механизмы взаимодействуют между собой для обеспечения качества различных систем высшего образования. Однако, несмотря на установление относительно одинаковой формь внешней системы обеспечения качества, существуют значительные различия в подходах к системе на национальном уровне.

Ключевые слова: высшее образование; внутренние органы обеспечения качества; внешние органы обеспечения качества; EC; система обеспечения качества образования.

Стаття надійшла до редакції 05.02.2018

Прийнято до друку 22.02.2018 